\title{
THE IMPLEMENTATION OF PRESIDENTIAL DECREE ON GENDER MAINSTREAMING: INSIGHTS FROM IAIN PONOROGO
}

\author{
Rohmah Maulidia* \\ Faculty of Sharia Institut Agama Islam Negeri Ponorogo, Indonesia \\ Email: maulidia77@yahoo.com
}

* Corresponding author

DOI: $10.21154 /$ justicia.v18i1.1841

\begin{tabular}{l|l|l}
\hline Received: Mar 5, 2020 & Revised: March 20, 2021 & Approved: May 17, 2021 \\
\hline
\end{tabular}

Abstract: This paper examines universities' role in achieving Sustainable Development Goals (SDGs) targets by conducting field research and using a policy theory approach. Theoretically, successful policy implementation depends on several aspects: communication, the availability of resources, the disposition, and the character of the bureaucracy. This study found that the State Institute for Islamic Studies (IAIN) Ponorogo contributed to implementing SDGs, especially in quality education and strengthening gender equality. However, the institution did not explicitly formulate other SDGs goals. Communication between the Institute for Research and Community Service (LPPM) as the leading sector for gender mainstreaming and leadership is manifested in the strategic plan and formal and informal meetings. Resources owned by IAIN Ponorogo in human resources and social capital are sufficient, which can be found from the active involvement of mass organizations of Fatayat, Muslimat, and Aisiyah in gender strengthening activities. The rector of IAIN Ponorogo collaborates with the Ministry of Women and Child Protection (KemenPPPA) to realize gender equality implementation agendas. Meanwhile, the bureaucratic structure that has been developed so far tends to be egalitarian and democratic. In preparing the Strategic Plan and the Master Plan (RIP), IAIN held a hearing with IAIN Ponorogo stakeholders, including the Academic Senate, which provides considerations for higher education policies. The problem is that the IAIN Ponorogo leader has not intensively monitored the targets for achieving gender equality, especially the other targets for achieving the SDGs.

Tulisan ini mengkaji lebih dalam bagaimana peran perguruan tinggi dalam pencapaian target SDGs, dengan cara melakukan field research dan menggunakan pendekatan teori kebijakan. Secara teoritik kesuksesan kebijakan sangat tergantung pada beberapa aspek seperti komunikasi, adanya sumber daya, disposisi dan watak birokrasi. Kajian ini menemukan bahwa IAIN Ponorogo turut berkontribusi melaksanakan pembangunan berkelanjutan, khususnya pada Pendidikan berkualitas dan penguatan kesetaraan gender, tetapi belum secara eksplisit merumuskan tujuan SDGs yang lain. Komunikasi antara Lembaga Penelitian dan Pengabdian Masyarakat (LPPM) sebagai leading sector pengarusutamaan gender dengan pimpinan diwujudkan dalam renstra, juga dalam rapat formal maupun informal. Sumberdaya yang dimiliki IAIN berupa sumberdaya manusia maupun sumberdaya sosial (social capital) sangatcukup. Terlihat dari keterlibatan aktif ormas Fatayat, Muslimat, Aisiyah dalam kegiatan gender di kampus. Adapun 
Rohmah Maulidia, The Implementation of Presidential Decree on Gender Mainstreaming ...

disposisidalam arti komitmendapatdilihatdari LPPM dan pimpinan IAIN menggandeng Kementerian Perlindungan Perempuan dan Anak (KemenPPPA) dalam mewujudkan agenda-agenda implementasi kesetaraan gender. Sedangkan struktur birokrasi yang dikembangkan selama ini cenderung egaliter dan demokratis. Dalam penyusunan renstra dan Rencana Induk Pengembangan (RIP), IAIN melakukan rapat dengar pendapat dengan stakeholder IAIN, termasuk dengan Senat Akademik sebagai lembaga pemberi pertimbangan kebijakan perguruan tinggi. Persoalannya adalah pimpinan lembaga IAIN belum secara intensif melakukan monitoring terhadap target pencapaian kesetaraan gender, terlebih target pencapaian SDGs yang lain. Kajian ini berkontribusi pada gagasan PTKI untuk lebih responsif terhadap SDGs.

Keywords: SDGs; Gender; IAIN Ponorogo.

\section{INTRODUCTION}

Universities have a strategic role in Indonesia's future development. Through the three pillars of higher education, universities are expected to alleviate poverty and create prosperity. According to Doni Koesoema, improving quality education can be achieved through policies that empower human resources. ${ }^{1}$ Sustainable Development Goals (SDGs) are committed to educational development. ${ }^{2}$

When delivering a speech at the summit to ratify the post-2015 development agenda at the United Nations (UN) headquarters, Jusuf Kalla stated that Indonesia was still facing severe problems regarding inequality, poverty, energy disparities, infrastructure, excessive consumption patterns, limited production, and climate change. ${ }^{3}$ In Spain, for example, according to the research of Alejandra Boto-Álvarez and Roberto García-Fernández, the government's efforts to achieve the SDGs target were carried out in stages. In detail, Alvarez explained the achievement of seventeen SDGs indicators in statistics. Spain hopes to achieve gender equality and empower all women. This optimism can be seen from the achievement of 5 out of 8 indicators to achieve the EU's value in 2030. Data in Spain shows that there has been an unfair reduction in the gender wage gap, the presence of women in parliament, national government, and education and training graduates. However, Spain is still weak in women's leadership positions, post-secondary education, and job opportunities for fresh graduates. ${ }^{4}$

Kompas, June 202018.

Ulisses Azeiteiro dan J. Paulo Davim, Higher education and sustainability: opportunities and challenges for achieving sustainable development goals (Boca Raton, FL: Taylor \& Francis Group, 2020).

“Wapres: MDGs Menyisakan Target yang Belum Berhasil dicapai," accessed December 2019, www. nasional.kompas.com.

4 Alejandra Boto-Álvarez dan Roberto García-Fernández, "Implementation of the 2030 Agenda Sustainable Development Goals in Spain,"21-22," Sustainability Journal 12 (2020): 2546, https://doi. org/10.3390/su12062546. Read also the SDGs research in Nigeria in the article Nnaemeka-Okeke Rosemary Chidimma, Okeke Francis Ogochukwu, dan Sam-Amobi Chinwe, "The 2030 Agenda for Sustainable Developmentin Nigeria: The Role of the Architect," Science, Technology \& Public Policy 4, no. 1 (2020): 15-21. 
Indonesia is also committed to the Sustainable Development Goals (SDGs) in Presidential Decree Number 59 of 2017. ${ }^{5}$ Perpres is the legislation stipulated by the President to carry out the orders of the higher laws and regulations or exercise government power. Based on Law no. 12 of 2011, then the types and hierarchies of Legislation in order from the highest are: The 1945 Constitution of the Republic of Indonesia (UUD 1945) Decree of the People's Consultative Assembly (Tap MPR) Law (UU) or Substitute Government Regulations Law (Perppu) Government Regulation (PP) Presidential Regulation (Perpres) Regional Regulation (Perda) Province Regency or City Regulation.

Through Presidential Decree Number 59 of 2017, the government has a serious commitment to alleviating poverty, hunger, health, etc. Bambang PS Brodjonegoro, as Minister of National Development Planning (2016-2019) in the foreword of the Roadmap book, stated that: ${ }^{6}$

Indonesia is committed to successfully implement the Sustainable Development Goals by achieving the 2030 development agenda. Indonesia's Presidential Regulation No. 59/2017 concerning the implementation of SDGs in Indonesia mandated the Ministry of National Development Planning of the Republic of Indonesia to provide the Roadmap of SDGs in Indonesia. The Roadmap of SDGs Indonesia was developed through a long process and discussion involving multi-stakeholder participation, ensuring that the roadmap's contents reflect all stakeholders' aspirations with rigorous exercises. The roadmap defines issues and projections of leading SDGs indicators in each goal, including its forward-looking policies to achieve such targets. There are around 60 selected indicators to include in the full version of the roadmap. This roadmap book presents a summary version of the roadmap that highlights only 29 selected indicators..... Therefore, the roadmap will be an essential tool to guide all stakeholders on the directions and targets of the Indonesian 2030 agenda by emphasizing a productive collaboration among stakeholders. A deep understanding that each goal and target of the 2030 agenda is interlinked will leverage one and another.

The SDGs are the direction and goals of development that have targets and indicators for their achievement from the above statement. Even long discussions have resulted in indicators of each target that is expected to be achieved by 2030. To achieve the goals, the government collaborates with all sectors, both universities, the private sector, and the wider community, to monitor its implementation in the field. Before the SDGs, development commitments were directed at achieving the Millennium Development Goals (MDGs). The unsuccessful MDGs target, which

\footnotetext{
"Ministry of Development Planning/National Developmnent Planning Agency, Roadmap of SDGs Indonesia: A Highlight," accessed August 2019, https:/ / www.unicef.org/indonesia.

6 Book Roadmap SDGs, t.t., iii. See also Tristan McCowan, Higher Education for and beyond the Sustainable Development Goals, Palgrave Studies in Global Higher Education (Cham: Springer International Publishing, 2019), https://doi.org/10.1007/978-3-030-19597-7.
} 
Rohmah Maulidia, The Implementation of Presidential Decree on Gender Mainstreaming ...

ended in 2015, remains a problem. The MDGs have eight goals, 18 targets, and 67 indicators. Indonesia has only succeeded in achieving 49 of the 67 indicators set from the targets. ${ }^{7}$

The transformation from MDGs to SDGs is described in detail in work Menuju Indonesia 2030. The facts show two weaknesses of the MDGs: MDGs are too focused on social development issues and too dependent on government policies. Therefore, there are needs to improve the MDGs' weaknesses, in which the approach was initially top-down. The approaches of MDGs were also too inter-governmental and exclusively UN-owned. The approach has changed to a bottom-up through SDGs. The SDGs put forward a participatory approach involving many non-governmental actors (academia, business sector, and civil society including indigenous peoples, women, youth, and children), and SDGs are more inclusive. ${ }^{8}$

Figure 1: Comparison of the MDGs and SDGs approach

\begin{tabular}{l|l}
\hline \multicolumn{1}{c|}{ MDGs } & \multicolumn{1}{c}{ SDGs } \\
\hline $\begin{array}{l}\text { Dominantly using a top-down } \\
\text { approach }\end{array}$ & Prioritizing a bottom-up approach \\
\hline $\begin{array}{l}\text { Focusing only on aspects of social } \\
\text { development }\end{array}$ & $\begin{array}{l}\text { Having more focuses but integrative, } \\
\text { covering social and cultural aspects, } \\
\text { economics, and the environment }\end{array}$ \\
\hline $\begin{array}{l}\text { More emphasizing on developing } \\
\text { and emerging countries }\end{array}$ & For all countries without exception \\
\hline
\end{tabular}

The Ministry of National Development Planning (Bappenas) organized an effort towards sustainable development by launching the Fiqh book that discusses SDGs. The book was initiated by Baznas, Indonesian Philanthropy, and UIN Syarif Hidayatullah with the Ministry of National Development Planning (Bappenas) and the Ministry of Religion. The book is an essential reference for stakeholders to understand the implementation of SDGs from Islamic perspectives based on the Qur'an, hadiths, and several opinions of scholars. The book also explains the

\footnotetext{
The unsuccessfulness of the MDGs is a evaluation record. Indonesia has not been able to reduce poverty and maternal mortality.Read moreLisbet, "Pencapaian Millenium Development Goals (MDGs) di Indonesia Melalui Kerjasama Internasional," Jurnal Politica 4, no. 1 (2013): 129-52.See alsoIndonesia Belum Mampu Mengurangi Angka Kemiskinan, 2019, https://ugm.ac.id.; Safrawati, "Pencapaian Tujuan MDGs Bidang Kesehatan Di Indonesia," Jurnal Kesehatan Masyarakat I, no. 1 (September 2006): 1-4; Elisa Roma dan Paul Jeffrey, "Evaluation of Community Participation in The Implementation of Communitybased Sanitation System: a Case Study From Indonesia," Water Science and Technology 62, no. 5 (2010): 1028-36.

8 Inspirator Muda Nusantara, Menuju Indonesia 2030 SDGs: Buku Petunjuk Dasar Mengenai Tujuan Pembangunan Berkelanjutan (Bandung: Ispirator Muda, 2017), 11-12.
} 
enormous potential of zakat in Indonesia to support SDGs' achievement, which helps utilize practical, physical and empowerment programs. As a system, zakat helps stimulate economic and entrepreneurial activity to overcome poverty and inequality, ensure financial and social stability, and promote comprehensive and equitable human development. ${ }^{9}$

According to Pirac's research, most philanthropic institutions strongly support the commitment to achieve the SDGs in Indonesia. To increase the role and involvement of philanthropic institutions in achieving SDGs, in 2014, the SDGs Philanthropy Platform was launched to facilitate international dialogue to collaborate between philanthropic institutions, which started in several pilot countries, such as Ghana, Indonesia, Kenya, and Colombia. ${ }^{10}$

The Platform focuses on efforts to incorporate philanthropy in the development landscape by helping philanthropic institutions better understanding opportunities to engage in global development processes and goals. Pirac's research examines philanthropic institutions' readiness to achieve the SDGs by analyzing perceptions, understanding, acceptance, commitment, and organizational capacity. The basic assumption is that the optimization and contribution of philanthropic institutions in supporting SDGs will be strongly influenced by the level of understanding, acceptance, commitment, and capacity of philanthropic organizations and their resources in supporting SDGs programs. Therefore, the philanthropic sector's works focused on community development can be aligned with the SDGs' goals. ${ }^{11}$

Pirac took respondents and research informants from 85 philanthropic organizations, namely family philanthropic foundations, corporate philanthropic foundations, religious, philanthropic foundations, mass media philanthropic foundations, and intermediary organizations. ${ }^{12}$

Unlike philanthropic institutions' involvement in SGDs, little research involving the Islamic State Higher Education (PTKIN)'s commitment to SDGs has been conducted. In contrast, Bappenas, as the leading SDGs sector institution,

9 Muhammad Maksum, Fikih Zakat on SDGs (Jakarta: Filantropi Indonesia, 2018); Kajian Zakat dan SDGs onHandi Khalifah, Soleh Nurzaman, dan Cholil Nafis, "Optimization of Baznas Programs on SDGs," International Journal of Zakat 2 (t.t.): 71-83.See alsoBappenas, "Fiqih Zakat on SDGS," accessed August 2019, www.antaranews.com.

10 Kesiapan Lembaga Filantropi Indonesia dalam Mendukung Pencapaian SDGs, 2019, 1, http:/ / www.pirac.org. See also Crespo dkk., "The Sustainable Development Goals"; See also Maia Chankseliani dan Tristan McCowan, "Higher Education and the Sustainable Development Goals," Higher Education 81, no. 1 (January 2021): 1-8, https:/ / doi.org/10.1007/s10734-020-00652-w.

11 Kesiapan Lembaga Filantropi Indonesia dalam Mendukung Pencapaian SDGs.

12 Kesiapan Lembaga Filantropi Indonesia dalam Mendukung Pencapaian SDGs, 1-2.Pirac uses mixed methods by combining quantitative and qualitative methods. Data were collected through document / literature review, surveys, in-depth interviews and FGD (Focus Group Discussion). The selection of respondents for surveys and informants for in-depth interviews and FGDs was carried out using a purposive method by taking into account the representation of each type of philanthropic institution. 
emphasizes the need for partnerships to achieve SDGs in the country. Therefore, global engagement and partnerships between government, civil society, the private sector, and academia are keys to the SDGs' success. For this reason, this paper will examine how the Islamic Higher Education Institution, in this case, IAIN Ponorogo, responds in the form of policies in achieving SDGs. Involving Islamic education institutions aware of the SDGs is very important, considering that public universities cannot achieve the SDGs alone.

\section{EDUCATIONAL INSTITUTION INVOLVEMENT}

The government's efforts to collaborate with universities in achieving the SDGs have been made. Bappenas looks forward to the role of universities in achieving the SDGs. These roles include transferring knowledge, innovation, and solutions to the 17 problems in the SDGs. Besides, universities can support and implement SDGs in campus management.

Brodjonegoro thought that several universities abroad had successfully collaborated with the government in achieving the SDGs. The four campuses mentioned, Monash University, Macquarie University, Victoria University of Wellington, and the University of Technology Sydney, can become best practices for implementing SDGs. ${ }^{13}$

Bappenas then established SDGs centers in several universities. In February 2019, SDGs centers were on seven campuses, namely Padjajaran University, Hasanuddin University, Mataram University, Jember University, Bengkulu University, Bogor Agricultural Institute Bandung Institute of Technology. Universities are expected to map their activities aligned with SDGs, including integrating SDGs into Community Service Program (KKN) courses and activities. ${ }^{14}$

Several years ago, on 4 October 2016, INFID held an expert discussion entitled "The Role of Universities and Local Governments in Achieving SDGs," presenting speakers, rectors from six universities, and four regents / Deputy Regents of Regional Government. The six universities explain the roles that can or have been done, even before the SDGs were released. Several universities define the roles, for example, Sunan Kalijaga State Islamic University and Gadjah Mada University (UGM) in Yogyakarta. Sunan Kalijaga State Islamic University has

13 Parulian Silalahi, "Resmikan SDGs Center Universitas Hasanuddin, Menteri Bambang: Kampus Sangat Berperan Dalam Mencapai TPB/SDGs," accessed February12, 2019, 1-2.

14 Silalahi, "Resmikan SDGs Center Universitas Hasanuddin, Menteri Bambang: Kampus Sangat Berperan Dalam Mencapai TPB/SDGs."The four campuses have collaborated with the Australia/ Pacific Sustainable Development Solution Network (SDSN) to prepare guidelines that govern theGetting Started with the SDGs in Universities strategy. In addition, the success of the Royal Institute of Technology Sweden (RITS) which has produced a center of excellence with a product called the Data Act Lab also deserves inspiration. The Data Act Lab produces an online collaboration platform or goal tracker to monitor progress and achievement of indicators in the respective TPB/SDGs goals in Sweden. 
pursued it through the curriculum and establishing study centers and dialogue centers to support the SDGs implementation. These methods strengthen the SDGs discourse that is inclusive, non-discriminatory, peaceful, progressive, and more broadly. This development is the result of the cooperation of various elements. With the strength of the network, Sunan Kalijaga State Islamic University influences the allocation and distribution of resources needed to achieve the SDGs. Also, with the financial support, Sunan Kalijaga State Islamic University plays a role by allocating resources that support the SDGs' achievement. ${ }^{15}$

Meanwhile, Gadjah Mada University (UGM) has been declared as a Socio Entrepreneur University. UGM has been around for 67 years, but currently, gaps and poverty still exist. Therefore, Socio Entrepreneur University's point is how universities should carry out the Three Pillars of Higher Education and not stop knowledge production or e-journals. UGM does not want to pursue world ranking. UGM has decided to become a village university with community service. ${ }^{16}$

Another example is Soegijapranata Catholic University. This campus declares as a transformative university. Regarding the SDGs, Soegijapranata Catholic University focuses on two goals, namely goals 8 and 11. Interventions that can be carried out in research are developing sustainable city innovation, creating a model for sustainable urban expansion, developing a model for Micro, Small, Medium Enterprises (UMKM), and developing models to improve the quality of human resources. ${ }^{17}$

Unlike the universities above, Hasanudin University (UNHAS) focused on developing coastal areas and small islands. Under the vision of UNHAS to strengthen and elevate the uniqueness of the maritime continent by realizing service and structuring, there are at least 7 SDGs targets that have been accomplished. There are goals 1, 2, 4, 6, 7, 13, and 14. UNHAS formed a center of excellence with the Small Island Growth, Resilience, and Sustainability (SIGRAS) program to support SDGs targets in Indonesia's Coastal Areas and Small Islands (WP3K).

Meanwhile, SebelasMaret State University (UNS) built the SDGs Study Center, which coordinated all study centers in LPPM and faculties in UNS and opened a network with local private universities to become the "UNS SDGs Network."Widya Mandira Catholic University also established an SDGs study center, a collaboration between the university and assisted villages, which was also actively involved in drafting a regional regulation draft. ${ }^{18}$

15 Sekar Panuluh dan Meila Riskia Fitri, "Perkembangan Pelaksanaan Sustainable Development Goals Di Indonesia," INFID Briefing Paper 2 (October 2016): 16-17.

16 Panuluh dan Fitri. See also Heleta dan Bagus, "Sustainable Development Goals and Higher Education."

17 Panuluh dan Fitri, "Perkembangan Pelaksanaan Sustainable Development Goals Di Indonesia," 18.

18

Panuluh dan Fitri, "Perkembangan Pelaksanaan Sustainable Development Goals Di Indonesia."The

University of Indonesia is one of the universities which is ranked 80th in the world as a university 
Rohmah Maulidia, The Implementation of Presidential Decree on Gender Mainstreaming ...

\section{CONTRIBUTION OF IAIN PONOROGO TO SDGs GENDER EQUALITY}

Since 2018, Ponorogo Regency has been familiar with the SDGs concept. According to Sumarno, head of the Regional Research and Development Planning Agency (Bappeda-Litbang) of PonorogoRegency, 16 of the 17 SDGs objectives have been listed in the Regional Medium Term Development Plan (RPJMD) of Ponorogo Regency. Examples are improving health services, reducing poverty, increasing access to education, and improving agriculture quality. ${ }^{19}$

However, the SDGs issue has not become a commitment of the State Islamic Institute of Religion (IAIN)Ponorogo. IAIN Ponorogo has not had a direct response to the seventeen SDGs targets. Moreover, the term SDGs was initially being only known by academics on that campus. However, IAIN Ponorogo has achieved the SDGs target number 5, gender equality and women empowerment. This can be seen from gender-responsive policies and activities that support women's empowerment since 2017.

In general, according to Basuki, as Vice-Rector I, to understand the direction of IAIN Ponorogo policy, this can be observed from the vision of the institution and the Master Plan (RIP) document. RIPis a planning instrument that is part of the institute's general policy and is used to establish policies, procedures, and implementation of the Three Pillars of Higher Education tasks arranged in a planned, integrated, and systematic manner.

The vision of IAIN Ponorogo is to become a center for studying and developing Islamic science, which excels at manifesting civil society. The first mission is to produce scholars in Islamic sciences who excel in material studies and research. The second mission is to produce scholars who are capable of manifesting civil society. The last mission is to produce scholars with character and tolerance. Referring to the IAIN Ponorogo Statute, IAIN Ponorogo governance is formulated in detail. In carrying out their duties, each leader of an organizational unit/work unit within the institute must apply coordination, integration, and synchronization with organizational units/work units. Carrying out coordination and consultation with the Ministry is the last step.

The leaders supervise their personnel, and if there is something wrong, they will take the necessary steps following the regulation. All parties have to follow, comply with instructions, and be responsible to their respective leaders. Everyone should also submit periodic reports following applicable regulations. Every leader of an organizational or work unit within the institute who receives a report from

that is serious about providing SDGs-based economic and social impactsaccording to the Times Higher

Education (THE) rating agency.Read“9 PTN Masuk Peringkat Berdampak SDGs, Ini Tanggapan

Kemendikbud dan Rektor," accessed July20, 2020, https:/ / edukasi.kompas.com.

19 "RJPMD Ponorogo Sudah Sesuai SDGs," accessed July 20 2020, www.ponorogo.go.id. 
the head of an organizational unit under him/her is obliged to process and use the report according to his/her needs and authority. In general, the development direction is carried out through the following stages below. ${ }^{20}$

Figure 2: Strategic Intent

\begin{tabular}{|c|c|c|c|c|}
\hline $\begin{array}{l}\text { Components } \\
\text { / Stages (road } \\
\text { map) }\end{array}$ & $\begin{array}{l}\text { Stage I } \\
\text { Teaching } \\
\text { University } \\
2012-2018 \\
\text { Commitment Stage } \\
\text { (State Islamic } \\
\text { Higher Education } \\
\text { (PTAIN) which } \\
\text { is based on } \\
\text { education/ } \\
\text { teaching)) }\end{array}$ & $\begin{array}{l}\text { Stage II } \\
\text { Excellent } \\
\text { Teaching } \\
\text { University } \\
2019-2022 \\
\text { Stabilization } \\
\text { Stage } \\
\text { (Flagship } \\
\text { PTAIN in } \\
\text { Education/ } \\
\text { Teaching) }\end{array}$ & $\begin{array}{l}\text { Stage III } \\
\text { Pre-Research } \\
\text { University } \\
2023-2026 \\
\text { Growth Stage } \\
\text { (PTAIN } \\
\text { with a solid } \\
\text { foundation } \\
\text { to become } \\
\text { a research } \\
\text { university) }\end{array}$ & $\begin{array}{l}\text { Stage IV } \\
\text { Research University } \\
2027-2030 \\
\text { Sustainable Growth } \\
\text { Stage } \\
\text { (PTAIN, which } \\
\text { has excellence in } \\
\text { producing research } \\
\text { for the development } \\
\text { of science and } \\
\text { society) }\end{array}$ \\
\hline Target & $\begin{array}{l}\text { The teaching } \\
\text { system is sound. } \\
\text { The process } \\
\text { (transfer of } \\
\text { knowledge) is } \\
\text { maintained and } \\
\text { value-based with } \\
\text { the addition of new } \\
\text { study programs } \\
\text { (undergraduate } \\
\text { and postgraduate) } \\
\text { and internal } \\
\text { quality assurance } \\
\text { through Internal } \\
\text { Quality Assurance } \\
\text { System (SPMI) and } \\
\text { External Quality } \\
\text { Assurance System } \\
\text { (SPME) with } \\
\text { accreditation values } \\
\text { A and B so that } \\
\text { at this stage State } \\
\text { Islamic College } \\
\text { (STAIN)Ponorogo } \\
\text { has changed to } \\
\text { IAIN }\end{array}$ & $\begin{array}{l}\text { Excellent } \\
\text { in teaching: } \\
\text { Research-based } \\
\text { Teaching. At } \\
\text { this stage, } \\
\text { new general } \\
\text { undergraduate } \\
\text { and graduate } \\
\text { study programs } \\
\text { under the } \\
\text { Ministry of } \\
\text { Education and } \\
\text { Culture have } \\
\text { been opened }\end{array}$ & $\begin{array}{l}\text { The stability } \\
\text { of the teaching } \\
\text { process and } \\
\text { the increase in } \\
\text { the quantity } \\
\text { and quality of } \\
\text { research that } \\
\text { is oriented } \\
\text { towards local } \\
\text { uniqueness } \\
\text { so that at the } \\
\text { end of this } \\
\text { stage, IAIN } \\
\text { has become a } \\
\text { State Islamic } \\
\text { University } \\
\text { (UIN), then } \\
\text { continued } \\
\text { with the } \\
\text { opening of new } \\
\text { postgraduate } \\
\text { study programs } \\
\text { under the } \\
\text { Ministry of } \\
\text { Religion }\end{array}$ & $\begin{array}{l}\text { Producing research } \\
\text { that can increase } \\
\text { competitive } \\
\text { advantage } \\
\text { (reputation, } \\
\text { credibility, and } \\
\text { funds) and become } \\
\text { an excellent/world- } \\
\text { class university }\end{array}$ \\
\hline
\end{tabular}

Sustainable Development Goals (SDGs) are a global action plan agreed upon by world leaders, including Indonesia, to end poverty, reduce inequality,

20 See "RIP IAIN Ponorogo," t.t., 16. See also Taya Louise Owens, "Higher Education in the Sustainable Development Goals Framework," European Journal of Education 52, no. 4 (December 2017): 414-20, https://doi.org/10.1111/ejed.12237. 
and protect the environment. The SDGs contain 17 Goals and 169 Targets that are expected to be achieved by 2030. IAIN Ponorogo has made strategic steps aligned with SDGs development from the seventeen aspects of SDGs development focus. For example, in reducing poverty, IAIN Ponorogo sides with the poor by establishing the Labzis Zakat Institute. Furthermore, IAIN Ponorogo strives for quality education by increasing the number of lecturers to obtain the doctoral degree, adding facilities and infrastructure on the new campus, and collaborating with various parties to attain achievement scholarships. Likewise, IAIN Ponorogo commits to gender mainstreaming and eliminating discrimination against women, aligning with the fifth SDGs goal. ${ }^{21}$

Basuki, as Vice-Rector I and Agus Purnomo as Vice-Rector II, said that all IAIN Ponorogo policies have not fully correlated with the SDGs programs. The reason is that, formally, the stakeholders of IAIN Ponorogo have never received instructions or cooperation with Bappenas. Furthermore, structurally Bappenas has the responsibility to succeed in the SDGs. However, according to both, IAIN commits to gender equality. As vice-Rector II, Agus Purnomo stated that there was always a gender-based research fund allocation every year, approximately 20 percent. Besides, gender research topics vary and implement, for example, gender and education, law, human rights, and gender. Moreover, a curriculum in the undergraduate and graduate studies with a gender perspective, a gender inclusion workshop among lecturers, and collaboration between IAIN Ponorogo and the Ministry of Women and Child Protection (KemenPPPA) show that IAIN Ponorogo is actively involved in gender equality campaigns. ${ }^{22}$

The agreement between IAIN Ponorogo and KemenPPPA, as explained by Agus Purnomo and Basuki above, was manifested in a curriculum workshop with a Gender Social Inclusion (GSI) perspective among IAIN Ponorogo lecturers. On July 26, 2017, the Minister of Women's Empowerment and Child Protection (PPPA), Yohana Yembise, together with six rectors of Islamic Higher Education (PTKI), agreed to sign a Memorandum of Understanding on "Strengthening Gender Responsive Academic in the Islamic Higher Education Environments" in the PPPA Ministry, Jakarta. The six rectors are UIN Raniry Banda Aceh, UIN Mataram, IAIN Ternate, North Maluku, IAIN Sultan Maulana Hasanuddin Banten, IAIN Ponorogo, East Java, and Islamic Institute of Sultan Muhammad Syarifuddin (IAIS) Sambas, West Kalimantan. The Minister of PPPA appreciated the 6 PTKIs committed to being part of the PPPA Ministry as agents fighting for the protection of women and children and the achievement of gender equality.

${ }_{21}$ Basuki and Agus Purnomo, Interviews and Focus Group Discussions with researchers and the Quality Assurance Agency team, August 2019.

22 Basuki and Purnomo. Interview, August 2019 
The government has mandated the importance of Gender Mainstreaming (PUG) in national development, which is mandated to all leaders of Ministries/Institutions and Regional Leaders following their respective duties, functions, and authorities. ${ }^{23}$

Yohana hoped that the agreement could prevent acts of discrimination, violence, exploitation, and other mistreatments of women and children in society, and ensure all levels of society, both men and women, have access to participation, control, and the benefits of development. Furthermore, Minister Yohana said that one of the challenges in implementing PUG was the community's understanding of gender equality, which was influenced by a local culture built from inaccurate religious understanding/ interpretations that lead to discriminatory and violent practices. Therefore, to prevent violence and manifest Gender Justice and Equality $(\mathrm{KKG})$, this is necessary to involve all parties, including universities. Universities have an essential and strategic role because they can transmit knowledge, values, norms, and ideology and shape the nation's character, including gender equality and justice. The six PTKINs are expected to fully integrate gender perspectives in their curriculum (education, teaching, and research/studies) to understand, knowledge, attitudes, and behaviors about gender equality are correct. They will continuously be brought up and institutionalized in society through their roles as community leaders, educators, school principals, pesantren heads, and preachers.

According to Agus and Basuki, gender strengthening activities were also carried out intensively through the Family Assistance Workshop with the theme Family Assistance Workshop with the Perspective and Approach of Mubadalah (Justice and Resentment of Male and Female Relations). ${ }^{24} \mathrm{He}$ added that the Institute for Research and Community Service (LPPM) IAIN Ponorogo has clear objectives for these activities, namely: ${ }^{25}$

1. The formulation of a society that can understand the ideas and concepts of mubadalah about gender relations in Islam;

2. Society can understand marriage, family, and household issues from the perspective of mubadalah;

3. Assisting the community in increasing knowledge related to perspectives, methods, and family assistance in mubadalah approach;

4. The establishment of a paradigm for Indonesian women that is appropriate to Indonesian culture and current development.

The workshop target was that participants could understand the ideas and concepts of mubadalah about gender relations in Islam. Participants were able

23 "Komitmen Kemenpppa Dan Perguruan Tinggi Keagamaan Islam (PTKI) Dalam Mewujudkan Kesetaraan Gender," accessed August 2019, www.kemenpppa.go.id."

24 Basuki dan Purnomo, Interviews and Focus Group Discussions with researchers and the Quality Assurance Agency team.

25 Basuki dan Purnomo. Interview August 2019. 
to understand marriage, family, and household issues from the perspective of mubadalah. Participants had knowledge related to perspectives, methods, and family assistance in the mubadalah approach. The workshop's targets werethe headmen inPonorogo Regency, IAIN Ponorogo lecturers, and IAIN Ponorogo students. ${ }^{26}$

On 14 October 2019, LPPM also conducted a workshop on drafting genderresponsive Semester Lesson Plan (RPS) materials for IAIN Ponorgo lecturers. This idea is an essential part of the process of internalizing gender in the lectures. The lecturers were guided by a speaker from the University of Indonesia, Iklilah Muzayyanah, in drafting a course plan with a gender perspective. This activity's expected impact is to strengthen equality and justice and reject the values of inequality and injustice. ${ }^{27}$

Figure 3: Changed achieved through RPS and Gender Responsive Lecturers

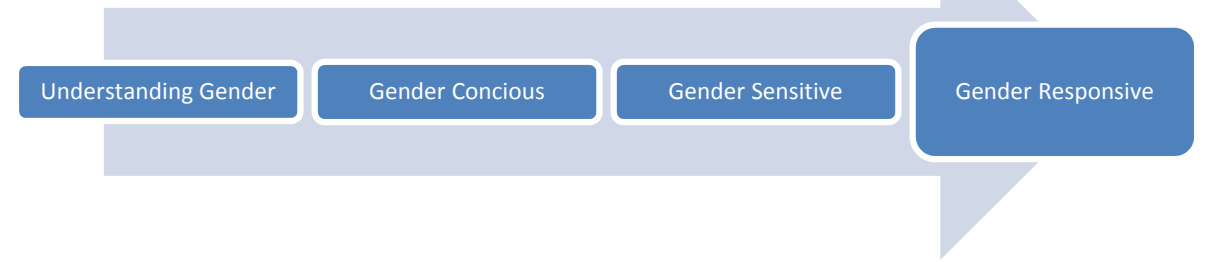

According to Nanda, the 3rd semester Sharia faculty-student, the lecturer has given RPS a gender perspective at the beginning of lectures. When studying the History of Islamic Civilization course, the lecturer explained that the Prophet's period was full of values that glorify women. Also, the lecturer mentioned women, Muslim scholars. The examples are Aisyah, the wife of the Prophet himself, and Khaulah Binti Tsa'labah, in which the story told the enforcement of women's rights. ${ }^{28}$

This was reinforced by Alifatul, who stated that in addition to the History of Islamic Civilization course, the lecturers from other subjects had also provided RPS with a gender perspective, for example, the Sharia Economic History course. The lecturer also explained the Prophet's wife, Khadijah. She was an enviable economic figure. The lecturer also explained modern Muslim women economists

26 The workshop was held on Thursday, February 28, 2019 starting at 08.00 until 16.30 in IAIN Ponorogo Postgraduate Hall opened by Vice Rector II, Agus Purnomo. The workshop was attended by 90 participants, with details: headmen in Ponorogo Regency (21 people), IAIN Ponorogo lecturers (40 people), and IAIN Ponorogo students (29 people). Nurkholis, one of the heads of the Religious Affairs Office (KUA) who participated in the mubadalah workshop said that he was very happy to be invited to the workshop because the gender insight gave him a new perspective on the annoyance of men and women. He is also grateful to get the reference book of mubadalahfrom the author, KH. Faqihuddin.

27 Nurul Kasanah, Interview, October 20, 2019.

28 Nanda, Interview, September 2, 2019. 
in Indonesia, such as Dian Masyita from Bandung, who received international awards. The lecturer also gave an example of the sharia economy empowerment in the millennial era carried out by contemporary Muslim women in Indonesia. ${ }^{29}$

The gender equality in IAIN Ponorogo can also be seen in the Community Service Lecture (KPM) activities. Thematically, KPM in IAIN Ponorogo is directed to mosque-based family empowerment post. Therefore, KPM activities lead to religious aspects. However, according to Field Supervisory Lecturers (DPL), Endrik Safudin and Ahmad Baihaqi, gender-focused activities were also carried out at KPM, for example, providing training and economic empowerment for women, integrated service post activities for infant health, counseling of women's health and information about cervical cancer prevention and pap smear. ${ }^{30}$

\section{CRITICAL NOTES OF POLICY THEORY PERSPECTIVE}

According to James E Anderson, as quoted by Islamic and Hayat, public policies are policies that government agencies and officials develop. ${ }^{31}$ According to Edward's view, there are 4 (four) variables that influence policy implementation. The first variable is communication. To succeed in policy implementation, implementers should know what to do. The policy's goals and objectives should be transmitted to the target group to reduce distortions in the implementation. The second variable is the resources. Even though the policy's content has been communicated clearly and consistently, the implementation will not be effective if the resources are insufficient. These resources can be in the form of human resources or non-human resources. The third variable is disposition. Disposition is the implementor's character and characteristics such as commitment, honesty, and democratic nature. The fourth variable is the bureaucratic structure. The bureaucratic structure in charge of implementing policies has a significant influence on policy implementation. ${ }^{32}$

According to Dunn (1994), the policy analysis process is a series of activities in a political activity process. This political activity is defined as a policy-making process and visualized as a series of interdependent stages, namely agenda

29 Alifatul, Interview, September 2, 2019.

30 Endrik Safudin, Interview, September 20, 2019; Ahmad Baihaqi, Interview, September 20, 2019.As a benchmarking, the Center for Gender and Child Studies of LPM and all stakeholders of IAIN Ponorogo can learn more broadly about the implementation of gender in universities in other countries.SeeI. Žalènienė dkk., "Gender Equality and Its Implementation in Universities of Lithuania," Economics and Sociology 9, no. 1 (2016): 237-51, https://doi.org/10.14254/2071-789X.2016/9-1/16.; Finnborg S. Steinthorsdottir dkk., "Gender Budgeting In Academia," Garcia Working Papers 14 (2016); Hilary P.M. Winchester dan Lynette Browning, "Gender Equality Inacademia: A Critical Reflection," Journal of Higher Education Policy and Management 37, no. 3 (2015): 269-81; United Nations Educational, Scientific and Cultural Organization, Global Education Digest 2010. Special focus on gender (Montreal, Quebec: UNESCO, 2010), www.uis.unesco.org/publications/GED2010.

31 Hayat, Kebijakan Publik: Evaluasi, Reformasi, Reformulasi (Malang: Intrans Publishing, 2018), 18.

32 Suharsono, Analisis Kebijakan Publik (Yogyakarta: Pustaka Pelajar, 2005), 90. 
setting, policy formulation, policy adoption, policy implementation, and policy assessment. $^{33}$

IAIN's policy supporting SDGs is not explicitly read in the RIP, nor does it appear in the institution's strategic plan or vision and mission based on the policy theory perspectives. However, gender activities can be found in the three pillars of accomplishments. Thus, IAIN could further initiate SDGs in the RIP and Renstra. RIP is part of the institute's policy and used as the basis for establishing policies, procedures, and the implementation of Three Pillars of Higher Education tasks that are planned, integrated, and systematic.

The vision of IAIN, as formulated, is towards a center for the study and development of Islamic science, which excels in manifesting evil society. This vision contains philosophical values that support the number one SDGs target regarding quality education and the 16th target of achieving world peace. The reason is that civilization's meaning in the vision is very close to science principles and creates tolerance among people. The manifestation of this vision is strengthened in the mission of IAIN.

The existence of gender training carried out by LPPM, gender workshops in the preparation of RPS, and mubadalah training proves IAIN's commitment to SDGs agenda number 5, namely efforts to build gender equality to eliminate discrimination. The initiation was encouraged by the Ministry of Women and Child Protection. Thus, parties did not fully initiate the initiatives of gender equality within the IAIN campus as policymakers. However, it was pushed by an outside institution, in this case, the Ministry of Women's Empowerment and Child Protection. ${ }^{34}$

Theoretically, the existence of external factors influencing policymakers is ordinary. According to Nigro and Nigro, as quoted by Islamic, there are at least five factors that can influence policymaking: ${ }^{35}$

1. The influence of external pressures

2. The influence of conservatism

33 Hayat, Kebijakan Publik: Evaluasi, Reformasi, Reformulasi, 25.

34 Suharsono, Analisis Kebijakan Publik, 31.Lecturers' research, thesis and thesis at IAIN Ponorogo also discusses gender. See Evi Muafiah dan Wirawan Fadly, "Pengasuhan Anak Usia Dini Berperspektif Gender Dalam Hubungannya Terhadap Pemilihan Permainan Dan Aktivitas Keagamaan Untuk Anak," Palastren 12, no. 1 (June 2019): 1-30; Isnatin Ulfah, "Menggugat Perkawinan: Transformasi Kesadaran Gender Perempuan dan Implikasinya terhadap Tingginya Gugat Cerai di Ponorogo," Kodifikasia 5, no. 1 (2011); Ridho Rokamah dan Rif'ah Roihanah, "Faktor Sosial dan Model Copying Perempuan," Justicia Islamica Jurnal Kajian Hukum dan Sosial 16, no. 2 (2019): 219-46; Anis Hidayatul Imtihanah, "Relasi Gender Keluarga Jamaah Tabligh," Hikmatuna: Journal for Integrative Islamic Studies 3, no. 1 (2017): 2-40.To continue its commitment to gender, IAIN can initiate an MoU with universities that have successfully implemented gender justice such as La Trobe University and Western Sydney University.See“Top Universities for Tackling Gender Equality," accessed July 20, 2020, https:/ /www. timeshighereducation.com.

35 Hayat, Kebijakan Publik: Evaluasi, Reformasi, Reformulasi, 31. 
3. The influence of personal traits

4. The influence from outside groups

5. The influence of past circumstances

It is common for policymakers to be significantly influenced by pressure from outside of higher education. There is also the existence of conservatism old bureaucratic habits that are difficult to change. The other reason is the influence of personality traits and attitudes and the leadership style of policymakers. The influence of social groups outside the campus and past conditions affecting policymakers' current perspective is also possible.

Furthermore, by referring to IAIN Ponorogo Statute, IAIN's governance was formulated in detail and well. In terms of its governance, all organizational units/work units within the institute must apply the principles of coordination, integration, and synchronization with organizational units/work units within the institute. They also need to carry out coordination and consultation with the ministry. These principles show that IAIN Ponorogo has a good communication pattern among elements, even with the central ministry structure. It also can be adaptive and progressive toward current development. Thus, as stated by Brodjonegoro, universities can contribute as much as possible to the success of the SDGs development.

For this reason, the role of IAIN's contribution, either directly or indirectly, has a significant impact on the development of the broader community without having to wait for instructions from Bappenas. IAIN's commitment to SDGs development can be carried out by including the SDGs program in the institutional roadmap agenda, either through suggestions in annual work meetings or routine meetings. ${ }^{36}$ This has been initiated by other PTKIN such as Sulthan Thaha Saifuddin State Islamic University Jambi, which prepared forms for the SDGs World University Ranking by the Times Higher Education. ${ }^{37}$

\section{CONCLUSION}

As emphasized by Bappenas, universities have a strategic role in the success of SDGs development. Through Three Pillars of Higher Education, the entire university academic community can participate in sustainable development. In

36 The implementation of SDGs in Higher Education can be read in full atSilvia Albareda-Tiana, Salvador Vidal-Raméntol, dan Mónica Fernández-Morilla, "Implementing The Sustainable Development Goals At University Level"," International Journal of Sustainability in HigherEducation 19, no. 3 (2018): 473-97; The Sustainable Development Solutions Network (SDSN) - Australia/Pacific in collaboration with the Australasian Campuses Towards Sustainability (ACTS) and the global SDSN Secretariat, Getting Started With The SDGs In Universities Australia, New Zealand \& Pacific Edition: A Guide For Universities, Higher Education Institutions, And The Academic Sector (Australia, SDSN, 2017), 2-52.

37 “Tiga PTKIN Masuk Ranking Dunia Versi UI Green Metric," accessed December 2020, www.diktis. kemenag.go.id." 
Rohmah Maulidia, The Implementation of Presidential Decree on Gender Mainstreaming ...

this case, IAIN Ponorogo has taken a small part in this effort. IAIN Ponorogo massively carried out a series of development goals number 5 (five), manifesting gender equality and eliminating all forms of discrimination against women. IAIN has also conducted curriculum and RPS with gender perspectives and published books, journals, monographs with gender perspectives. Through the increasing number of departments and study programs, supported by open leadership management and the ability to forge synergies with government agencies and public mass organizations, IAIN could play a more significant role in other development targets such as the climate change campaign manifesting world peace.

\section{REFERENCES}

Anonim, "9 PTN Masuk Peringkat Berdampak SDGs, Ini Tanggapan Kemendikbud dan Rektor," accessed July 20 2020. https:/ / edukasi.kompas.com.

Albareda-Tiana, Silvia, Salvador Vidal-Raméntol, dan Mónica FernándezMorilla. "Implementing The Sustainable Development Goals At University Level." International Journal of Sustainability in HigherEducation 19, no. 3 (2018): 473-97.

Alifatul. Interview, September 3, 2019.

Azeiteiro, Ulisses, dan J. Paulo Davim. Higher education and sustainability: opportunities and challenges for achieving sustainable development goals. Boca Raton, FL: Taylor \& Francis Group, 2020.

Baihaqi, Ahmad. Interview, September 20, 2019.

Bappenas. "Fiqih Zakat on SDGS," accessed August 2019. www.antaranews.com. Basuki, dan Agus Purnomo. Interview and Focus Group Discussion with researchers and the Quality Assurance Agency team, August 2019.

Boto-Álvarez, Alejandra, dan Roberto García-Fernández. "Implementation of the 2030 Agenda Sustainable Development Goals in Spain,"21-22." Sustainability Journal 12 (2020): 2546. https:/ / doi.org/10.3390/su12062546.

Buku Roadmap SDGs, t.t.

Chankseliani, Maia, dan Tristan McCowan. "Higher Education and the Sustainable Development Goals." Higher Education 81, no. 1 (January 2021): 1-8. https:/ / doi.org/10.1007/s10734-020-00652-w.

Chidimma, Nnaemeka-Okeke Rosemary, Okeke Francis Ogochukwu, dan SamAmobi Chinwe. “The 2030 Agenda for Sustainable Development in Nigeria: The Role of the Architect." Science, Technology \& Public Policy 4, no. 1 (2020): 15-21.

Crespo, Bárbara, Carla Míguez-Álvarez, María Elena Arce, Miguel Cuevas, dan 
José Luis Míguez. "The Sustainable Development Goals: An Experience on Higher Education." Sustainability 9, no. 8 (1 August 2017): 1353. https:/ / doi. org/10.3390/su9081353.

Hayat. Kebijakan Publik: Evaluasi, Reformasi, Reformulasi. Malang: Intrans Publishing, 2018.

Heleta, Savo, dan Tohiera Bagus. "Sustainable Development Goals and Higher Education: Leaving Many Behind." Higher Education 81, no. 1 (January 2021): 163-77. https:/ / doi.org/10.1007/s10734-020-00573-8.

Imtihanah, Anis Hidayatul. “Relasi Gender Keluarga Jamaah Tabligh.” Hikmatuna: Journal for Integrative Islamic Studies 3, no. 1 (2017): 2-40.

Indonesia Belum Mampu Mengurangi Angka Kemiskinan, 2019. https://ugm.ac.id. Kasanah, Nurul. Interview, October 20, 2019.

Kesiapan Lembaga Filantropi Indonesia dalam Mendukung Pencapaian SDGs, 2019. http://www.pirac.org.

Khalifah, Handi, Soleh Nurzaman, dan Cholil Nafis. "Optimization of Baznas Programs on SDGs." International Journal of Zakat 2 (t.t.): 71-83.

"Komitmen Kemenpppa Dan Perguruan Tinggi Keagamaan Islam (PTKI) Dalam Mewujudkan Kesetaraan Gender," accessed August 2019. www.kemenpppa. go.id.

Lisbet. “Pencapaian Millenium Development Goals (MDGs) di Indonesia Melalui Kerjasama Internasional." Jurnal Politica 4, no. 1 (2013): 129-52.

Maksum, Muhammad. Fikih Zakat on SDGs. Jakarta: Filantropi Indonesia, 2018. McCowan, Tristan. Higher Education for and beyond the Sustainable Development Goals. Palgrave Studies in Global Higher Education. Cham: Springer International Publishing, 2019. https://doi.org/10.1007/978-3-030-19597-7. “Ministry of Development Planning/National Development Planning Agency, Roadmap of SDGs Indonesia: A Highlight," accessed August 2019. https:// www.unicef.org/indonesia.

Muafiah, Evi, dan Wirawan Fadly. "Pengasuhan Anak Usia Dini Berperspektif Gender Dalam Hubungannya Terhadap Pemilihan Permainan Dan Aktivitas Keagamaan Untuk Anak." Palastren 12, no. 1 (June 2019): 1-30.

Nanda. Interview, September 2, 2019.

Nusantara, Inspirator Muda. Menuju Indonesia 2030 SDGs: Buku Petunjuk Dasar Mengenai Tujuan Pembangunan Berkelanjutan. Bandung: Ispirator Muda, 2017. Owens, Taya Louise. "Higher Education in the Sustainable Development Goals Framework." European Journal of Education 52, no. 4 (December 2017): 414-20. https://doi.org/10.1111/ejed.12237.

Panuluh, Sekar, dan Meila Riskia Fitri. "Perkembangan Pelaksanaan Sustainable 
Rohmah Maulidia, The Implementation of Presidential Decree on Gender Mainstreaming ...

Development Goals Di Indonesia." INFID Briefing Paper 2 (October 2016): 16-17.

"RIP IAIN Ponorogo," t.t.

“RJPMD Ponorogo Sudah Sesuai SDGs," accessed July 20, 2020. www.ponorogo. go.id.

Rokamah, Ridho, dan Rif'ah Roihanah. "Faktor Sosial dan Model Copying Perempuan." Justicia Islamica Jurnal Kajian Hukum dan Sosial 16, no. 2 (2019): 219-46.

Roma, Elisa, dan Paul Jeffrey. "Evaluation of Community Participation in The Implementation of Community-based Sanitation System: a Case Study From Indonesia." Water Science and Technology 62, no. 5 (2010): 1028-36.

Safrawati. "Pencapaian Tujuan MDGs Bidang Kesehatan Di Indonesia." Jurnal Kesehatan Masyarakat I, no. 1 (September 2006): 1-4.

Safudin, Endrik. Interview, September 20, 2019.

Silalahi, Parulian. "Resmikan SDGs Center Universitas Hasanuddin, Menteri Bambang: Kampus Sangat Berperan Dalam Mencapai TPB/SDGs," 12 February 2019.

Steinthorsdottir, Finnborg S., Thamar M. Heijstra, Thorgerdur Einarsdottir, dan Gyda M. Petursdottir. "Gender Budgeting In Academia." Garcia Working Papers 14 (2016).

Suharsono. Analisis Kebijakan Publik. Yogyakarta: Pustaka Pelajar, 2005.

The Sustainable Development Solutions Network (SDSN) - Australia/Pacific collaborated with the Australasian Campuses Towards Sustainability (ACTS) and the global SDSN Secretariat. Getting Started With The SDGs In Universities Australia, New Zealand E Pacific Edition: A Guide For Universities, Higher Education Institutions, And The Academic Sector. Australia, SDSN, 2017.

“Tiga PTKIN Masuk Ranking Dunia Versi UI Green Metric," accessed December 2020. www.diktis.kemenag.go.id.

“Top Universities for Tackling Gender Equality," accessed July 20, 2020. https:/ / www.timeshighereducation.com.

Ulfah, Isnatin. "Menggugat Perkawinan: Transformasi Kesadaran Gender Perempuan dan Implikasinya terhadap Tingginya Gugat Cerai di Ponorogo." Kodifikasia 5, no. 1 (2011).

United Nations Educational, Scientific and Cultural Organization. Global Education Digest 2010. Special focus on gender. Montreal, Quebec: UNESCO, 2010. www. uis.unesco.org/publications/GED2010.

“Wapres: MDGs Menyisakan Target yang Belum Berhasil dicapai," accessed December 2019. www. nasional.kompas.com. 
Winchester, Hilary P.M., dan Lynette Browning. "Gender Equality Inacademia: A Critical Reflection." Journal of Higher Education Policy and Management 37, no. 3 (2015): 269-81.

Žalènienè, I., E. Krinickienè, A. Tvaronavičienè, dan A. Lobačevskytè. "Gender Equality and Its Implementation in Universities of Lithuania." Economics and Sociology 9, no. 1 (2016): 237-51. https:// doi.org/10.14254/2071789X.2016/9-1/16.

Kompas, June 20, 2018. 